Acta Horticulturae et Regiotecturae - Special Issue

Nitra, Slovaca Universitas Agriculturae Nitriae, 2016, pp. 5-7

\title{
BIOTECHNICAL PREPARATIONS IN PROTECTION OF CUCUMBER AGAINST DOWNY MILDEW
}

\author{
Dorota TEKIELSKA, Stanisław MAZUR* \\ University of Agriculture in Krakow, Krakow, Poland
}

\begin{abstract}
The effectiveness of the preparations PB 500 (extracted from cow dung) and PB 501 (silica fume $-92.8 \% \mathrm{SiO}_{2}$ ) in protection of cucumber against downy mildew was tested during the two-years experiment. PB 500 was used at $2 \%$ concentration and PB 501 at $1 \%$ concentration. The alternative fungicides recommended by the standard protection program were used as the reference agents. The effectiveness of the preparations PB 501 and PB 500 was lower than the conventional fungicides. It was observed that the infestation of protected plants is lower than the control plants, although not statistically significant. The results indicate a limited possibility of application of the tested formulations for cucumber protection against downy mildew in comparison to the chemical protection.
\end{abstract}

Keywords: Downy mildew, Pseudoperonospora cubensis, silica fume, extract from cow manure, protection

Ground cucumber is a species commonly grown in Poland. The most dangerous disease of ground cucumber crops is downy mildew caused by Pseudoperonospora cubensis (Berk. \& M. A. Curtis) Rostovzev. Despite the introduction of varieties resistant or moderately resistant to $P$. cubensis, downy mildew continues to cause very large losses in the yield, which are additionally enhanced in the case of withdraw from the protection programs (Call et al., 2012). The pathogen is present in more than 80 countries with variety of climatic conditions, due to its high adaptability (Lebeda and Cohen, 2010). P. cubensis belongs to the most destructive disease factors of the cucumbers grown in the field and under cover in the whole of Central and SouthEastern Europe (Fanourakis et al., 2001; Lebeda and Urban, 2007) and Asia (Shi et al., 2002). P. cubensis has a wide host range, being able to infect about 20 different types of Cucurbitaceae, including cucumber, pumpkin and squash (Lebeda and Widrlechner, 2003; Lebeda and Urban, 2004; Palti and Cohen, 1980). It attacks mainly leaves, which may result in the decrease of photosynthesis efficiency, and as a result causes the dieback of the whole plant (Ojiambo et al., 2015). To prevent this decay the chemical protection is used, being expensive and thus not feasible from the economical point of view. In addition, chemical protection carries the risk of developing resistance to certain fungicides (Ishii et al., 2001). Therefore, studies were undertaken on the possible use of non-chemical preparations in protection of cucumber against downy mildew.

\section{Material and methods}

The field experiment was conducted in years 2014-2015 under the conditions regarding two preparations: PB
501 - containing silica fume $\left(92.8 \% \mathrm{SiO}_{2}\right)$, used at $1 \%$ concentration, and PB 500 (extracted from cow manure), used at $2 \%$ concentration. Various fungicides were used as the reference agents as recommended by the classic protection programme. Plants of cucumber, cultivar Andrus $F_{1}$ were sprayed, starting from the onset of visible disease symptoms. In 2014, 6 treatment sessions were scheduled from June 17 at intervals from 10 to 14 days. The last procedure was performed on $14^{\text {th }}$ August. In 2015, the first symptoms occurred on $9^{\text {th }}$ July which marked the date of the first spraying. A total of 8 treatments were performed with the last treatment performed on $31^{\text {st }}$ August. Two infestation assessments of the tested plants were undertaken during vegetation season: in 2014 after $3^{\text {rd }}$ and 6 th spraying and in 2015 after $4^{\text {th }}$ and $8^{\text {th }}$ spraying. For the infestation assessment 10 randomly chosen leaves from each plant were evaluated. Evaluation of infestation degree was carried out according to 4-degree scale (Haggag, 2002) where: 0 - no symptoms, 1 - symptoms on $25 \%$ or less of leaf area, 2 - symptoms from 26 to $50 \%$ o of leaf area, 3 - symptoms from 51 to $100 \%$ of leaf area. The infestation index was calculated, using the Townsend - Heuberger formula (Püntener, 1981). The percentage of the infected plants was calculated likewise. The yield was successively collected and weighed. The data were subjected to statistical analysis. The significance of differences between the mean values was assessed using the Duncan's test for the significance level $\alpha=0.05$.

\section{Results and discussion}

The preparations used for the protection of cucumber plants reduced infestation by $P$. cubensis, but at different rates, depending on the date of the analysis and the type 
of the preparation used (Table 1). In 2014, in the $1^{\text {st }}$ term of infestation assessment, the disease symptoms caused by $P$. cubensis occurred only in the case of control fields (Table 1 ). In the $2^{\text {nd }}$ term of the analysis, carried out after $6^{\text {th }}$ treatment session, symptoms of the disease occurred on all plants. The degree of plants' infestation in the tested combinations varied. During the $2^{\text {nd }}$ infestation analysis effective protection against downy mildew was observed mostly for the plants treated with the chemical fungicides recommended in the protection program. The plants treated with the tested preparations, as well as the control plants, were strongly infected. The infestation index ranged from 1.33 for chemical protected plants to 15.33 for control plants (Table 1). Use of preparations PB 501 and PB 500 reduced the infestation of leaves, but the effect was not statistically significant in comparison to the control (Table 1). It was also observed that the percentage of the leaves with disease symptoms was highest in the control, where symptoms were present on $46.67 \%$ of the leaves. The percentage of infected leaves decreased in the case of application of the PB 501 and PB 500, but not significantly. The smallest percentage of leaves with disease symptoms was observed in plants treated with the fungicides and these values were statistically significant compared to the control (Table 1). In 2015, similar trend of lower infestation index occurred on the fields, where the fungicides were used in both- the first and the second period of infestation evaluation (Table 2). It was observed that in 3 treatments (fungicides, PB 501 and PB 500) the infestation index was lower than in the control. However, the differences were significant only in the case of treatments with the PB 501 and fungicides in the $1^{\text {st }}$ term and the chemical protection in the $2^{\text {nd }}$ term (Table 2). Similar trends were observed in relation to the percentage of leaves with disease symptoms (Table 2). The applied chemical protection program against $P$. cubensis in cucumber reduced infestation, but did not have a statistically significant effect on the total yield in both years. It has been observed, however, that the plants treated with the PB 501 and the PB 500 in 2015 gave slightly higher yield than the control plants and plants protected with fungicides (Table 3). The PB 501 and PB 500's efficacy in reducing downy mildew infestation of cucumber was lower than effectiveness of the conventional fungicides, but in the case of all treatments, the infestation index was lower than in the control, although, not always statistically significant. Lower tendency of plants infection occurring after the application of the tested formulations indicates that, in case of a smaller pressure from the pathogen, they may protect the plants from further infection and disease progression. This is confirmed by the Haggag's (2002) results where kaolin (aluminum silicate) and Nu-Film (di-1P-menthene, low viscosity) were used to protect cucumber crops against downy mildew. These agents were effective in reducing the number of germinating spores and infections caused by $P$. cubensis. Moreover, the author indicates that this type of preparations is safer than chemical agents for people and the environment, and meets the requirement of costeffectiveness. Silicon, present in the product PB 501 used against $P$. cubensis in cucumber, is likely to stimulate the life processes of plants and takes part in the construction of plant resistance mechanism to biotic stress. An example of a beneficial effect of silicon on the cucumber are reported

Table 3 The influence of the applied protection agents on total yield $\left(\mathrm{kg} \mathrm{plot}^{-1}\right)$

\begin{tabular}{|l||c|c|}
\hline \multicolumn{1}{|l||}{ Treatment } & \multicolumn{2}{|c|}{ Year } \\
\hline Control & $\mathbf{2 0 1 4}$ & $\mathbf{2 0 1 5}$ \\
\hline PB 501 & $8.95 \mathrm{a}$ & $10.21 \mathrm{a}$ \\
\hline PB 500 & $9.57 \mathrm{a}$ & $12.04 \mathrm{a}$ \\
\hline Chemical protection & $8.26 \mathrm{a}$ & $13.28 \mathrm{a}$ \\
\hline
\end{tabular}

Means within columns with the same letter do not differ significantly according to the Duncan's test at $p=0.05$

Table 1 The influence of the applied protection agents on downy mildew severity in 2014

\begin{tabular}{|l||c|c|c|}
\hline \multirow{2}{*}{ Treatment } & \multicolumn{2}{|c|}{ I term } & \multicolumn{2}{c|}{ II term } \\
\cline { 2 - 4 } & Infestation index & Infected leaves (\%) & Infestation index \\
\hline \hline Control & $2.33 \mathrm{a}$ & $18.00 \mathrm{~b}$ & $15.33 \mathrm{C}$ \\
\hline PB 501 & $0.2 \mathrm{a}$ & $2.5 \mathrm{a}$ & $8.67 \mathrm{bc}$ \\
\hline PB 500 & $0.2 \mathrm{a}$ & $2.5 \mathrm{a}$ & $7.33 \mathrm{abc}$ \\
\hline Chemical protection & $0.2 \mathrm{a}$ & $0.5 \mathrm{a}$ & $37.33 \mathrm{ab}$ \\
\hline
\end{tabular}

Means within columns with the same letter do not differ significantly according to the Duncan's test at $p=0.05$

Table 2 The influence of the applied protection agents on downy mildew severity in 2015

\begin{tabular}{|l||c|c|c|}
\hline \multirow{2}{*}{ Treatment } & \multicolumn{2}{|c|}{ I term } & \multicolumn{2}{c|}{ II term } \\
\cline { 2 - 4 } & Infestation index & Infected leaves (\%) & Infestation index \\
\hline \hline Control & $8.33 \mathrm{c}$ & $35.55 \mathrm{c}$ & $32.78 \mathrm{~b}$ \\
\hline PB 501 & $4.44 \mathrm{ab}$ & $15.56 \mathrm{ab}$ & $27.22 \mathrm{~b}$ \\
\hline PB 500 & $7.22 \mathrm{bc}$ & $24.45 \mathrm{bc}$ & $28.33 \mathrm{~b}$ \\
\hline Chemical protection & $1.67 \mathrm{a}$ & $6.67 \mathrm{a}$ & $71.11 \mathrm{~b}$ \\
\hline
\end{tabular}

Means within columns with the same letter do not differ significantly according to the Duncan's test at $p=0.05$ 
by Kaussa'a et al. (2003): the test of cucumber plants infected by Colletotrichum lagenarium has shown that the induction of systemic immunity by strongly cationic protein rich in proline acts supportively towards cell walls, and thus the cell walls have an enhanced ability to accumulate silica. The effect of this is the initiation of chitinases, peroxidases and poliphenylooksydases'production. Silicon increases sunlight absorption, whereby the plants have a longer growing season, which significantly affects the increase in crop yield. It also causes decreased susceptibility to diseases and pests. The increased resistance to powdery mildew occurred in cucumber due to silicon treatment (Grzebisz, 2008). In the study conducted in 2014 and 2015, the yield obtained from PB 501 combination was higher than in control, but according to tests by Kingston (2008), it is not entirely clear whether the use of foliar silicon mould has actually a significant impact on the yield of plants. The PB 500 preparation used in this experiment showed comparable effectiveness as the PB 501 preparation for the prevention against downy mildew in cucumber crop. The PB 500 is used for a long time in biodynamic agriculture. There is no literature data regarding the effect of this preparation on plant health so far, but many publications indicate that it increases the life processes of plants improving their resistance to biotic and abiotic stress, and its role in biodynamic agriculture has long been recognized (Remer, 1995). The proper use of the product may increase the yield and improve its quality (Bacchus, 2010). Hence, our information obtained on the basis of two-year field experiments may indicate limited, in relation to chemical protection, prospect of using the products PB 500 and PB 501 for cucumber's protection against downy mildew.

\section{Coclusions}

1. The tested preparations PB 500 and PB 501 had a limited efficacy in reducing downy mildew severity in cucumber, although, the tendency of plants infection occurring after the treatments with the PB 500 and PB 501 was lower.

2. Prospect of using the products PB 500 and PB 501 for protection of cucumber against Pseudoperonospora cubensis is limited in relation to chemical protection, but in the case of a smaller pressure from the pathogen, they may protect the plants from further infection and disease progression.

\section{References}

BACCHUS, G. 2010. An evaluation of the influence of biodynamic practices including foliar-applied silica spray on nutrient quality of organic and conventionally fertilised lettuce (Lactuca sativa L.). In Journal of Organic Systems, vol. 5, no. 1, pp. 1-13. ISSN 11774258.

CALL, A. D. - CRISWELL, A. D. - WEHNER, T. C. - KLOSINSKA, U. KOZIK, E. U. 2012. Screeninig Cucumber for Resistance to Downy Mildew Caused by Pseudoperonospora cubensis (Berk. and Curt.) Rostov. In Crop Science, vol. 52, pp. 577-592. DOI: 10.2135/ cropsci2011.06.0296.

FANOURAKIS, N. E. - ILIAKI, I. - FANOURAKI, M. - PETSAS, S. 2001. New sources of resistance against the populations of downy mildew (Pseudoperonospora cubensis) of cucumber in Greece. In $2^{\text {nd }}$ International Symposium on Cucurbits, $28^{\text {th }}$ September $-1^{\text {st }}$ October, 2001, Epochal, Tsukuba, Japan, pp. 21 (abstract).
GRZEBISZ, W. 2008. Nawożenie roślin uprawnych i podstawy nawożenia. Poznań : WRiL, pp. 208-303. ISBN 978-83-09-99008-6.

HAGGAG, W. M. 2002. Application of epidermal coating antitranspirants for controlling cucumber downy mildew in greenhouse. In Plant Pathology Bulletin, vol. 11, pp. 69-78.

ISHII, H. - FRAAIJE, B. A. - SUGIYAMA, T. - NOGUCHI, K. NISHIMURA, K. - TAKEDA, T. - AMANO, T. - HOLLOMON, D. W. 2001. Occurrence and Molecular Characterization of Strobilurin resistance in Cucumber Powdery Mildew and Downy Mildew. In Phytopathology, vol. 91, no. 12, pp. 1166-1171. DOI: 10.1094/ PHYTO.2001.91.12.1166.

KAUSS, H. - SEEHAUS, K. - FRANKE, R. - GILBERT, S. - DIETRICH, R. A. KROGER, N. 2003. Silica deposition by a strongly cationic prolinerich protein from systemically resistant cucumber plants. In Plant Journal, vol. 33, pp. 87-95. DOI: 10.1046/j.1365-313X.2003.01606.x. KINGSTON, G. 2008. Silicon fertilisers: requirements and field experiences. In Silicon in Agriculture $4^{\text {th }}$ International Conference, Port Edward, South Africa, pp. 52.

LEBEDA, A. - COHEN, Y. 2010. Cucurbit downy mildew (Pseudoperonospora cubensis) - biology, ecology, epidemiology, host-pathogen interaction and control. In European Journal of Plant Pathology, vol. 129, no. 2, pp. 1-36. DOI: 10.1007/ s10658-010-9658-1.

LEBEDA, A. - URBAN, J. 2004. Disease impact and pathogenicity variation in Czech populations of Pseudoperonospora cubensis. In A. Lebeda, H. S. Paris (Eds.), Progress in cucurbit genetics and breeding research. Proceedings of Cucurbitaceae 2004, the $8^{\text {th }}$ EUCARPIA Meeting on Cucurbit Genetics and Breeding. Olomouc: Palacký University in Olomouc, Czech Republic, pp. 24-38.

LEBEDA, A. - URBAN, J. 2007. Temporal changes in pathogenicity and fungicide resistance in Pseudoperonospora cubensis population. In Acta Horticulturae, vol. 731, pp. 327-336. DOI: 10.17660/ ActaHortic.2007.731.44.

LEBEDA, A. - WIDRLECHNER, M. P. 2003. A set of Cucurbitaceae taxa for differentiation of Pseudoperonospora cubensis pathotypes. In Journal of Plant Diseases and Protection, vol. 110, pp. 337-349. ISSN 0340-8159.

OJIAMBO, P.S. - GENT, D. H. - QUESADA OCAMPO, L. M. - HAUSBECK, M. K. - HOLMES, G. J2015. Epidemiology and population biology of Pseudoperonospora cubensis: A model system for management of downy mildews. In Annual Review of Phytopathology, vol. 53, pp. 223-246.DOI: 10.1146/annurev-phyto-080614-120048.

PALTI, J. - COHEN, Y. 1980. Downy mildew of cucurbits (Pseudoperonospora cubensis): the fungus and its hosts, distribution, epidemiology and control. In Phytoparasitica, vol. 8, pp. 109-147. ISSN 0334-2123.

PÜNTENER, W. 1981. Manual for field trials in plant protection $2^{\text {nd }}$ edition. Podręcznik Doświadczalnictwa Polowego w Ochronie Roślin [translation and adaptation Z. Ginter]. Poznań : Inst. Ochr. Roślin, pp. 39-41.

REMER, N. 1995. Laws of life in agriculture. Bio-Dynamic Farming and Gardening Association Inc., Kimberton, Pennsylvania, 158 pp.

SHI, Y. - LI, B. J. - LIU, X. 2002. The study of cucumber downy mildew. In Journal of Northeast Agricultural University, vol. 33, pp. 391-395. 